\title{
Assessment of two sludge stabilization methods in a wastewater treatment plant in Sotaquirá, Colombia
}

\author{
José Castellanos-Rozo ${ }^{1, *}$, Jaqueline A. Galvis-López ${ }^{2}$, Nuri A. Merchán-Castellanos ${ }^{3}$, \\ Elsa H. Manjarres-Hernández ${ }^{1,4}$, Alex L. Rojas ${ }^{5}$
}

\section{Edited by}

Juan Carlos Salcedo-Reyes

(salcedo.juan@javeriana.edu.co)

1. Department of Biology and Microbiology, Universidad de Boyacá

2. Department of Chemistry and

Biochemistry, Universidad de Boyacá

3. Bacteriology and Clinical Laboratory

Program, Universidad de Boyacá

4. School of Biological Sciences,

Universidad Pedagógica y

Tecnológica de Colombia.

5. School of Mathematics and Statistics,

Universidad Pedagógica y

Tecnológica de Colombia.

* joscastellanos@uniboyaca.edu.co

Received: 20-12-2018

Accepted: 30-08-2019

Published on line: 24-02-2020

Citation: Castellanos-Rozo J, GalvisLópez JA, Merchán-Castellanos NA, Manjarres-Hernández EH, Rojas AL. Assesment of two sludge stabilization methods in a wastewater treatment plant in Sotaquirá, Colombia, Universitas Scientiarum, 25 (1): 17-36, 2020. doi: 10.11144/Javeriana.SC25-1.aots

Funding:

Universidad de Boyacá, Tunja, Colombia.

Electronic supplementary material: N.A.

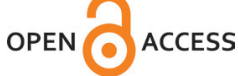

\begin{abstract}
Wastewater sludge is a by-product of wastewater treatment; it is often employed in agricultural processes following appropriate microbiological stabilization. In this study, we evaluated two methods of sludge stabilization in the wastewater treatment plant of Sotaquirá, Colombia. The two assessed stabilization methods were dewatering on drying beds and alkaline stabilization. The stabilization through dewatering on drying bed was carried out for five months. Alkaline stabilization was conducted for 96 hours with three concentrations of calcium oxide, $7 \%, 9 \%$, and $13 \% \mathrm{w} / \mathrm{w}$. Humidity, pH, organic carbon, phosphorus, organic nitrogen, fecal coliforms, somatic phages, total helminth eggs, and Salmonella sp. were monitored monthly for the sludge under dewatering treatment and at $0,12,24$ hours for sludge under alkaline stabilization treatment. Both treatments succeded in eliminating Salmonella sp. Helminth eggs were eliminated by alkaline stabilization, whereas it was reduced to one or zero helminth eggs with the dewatering treatment. Somatic phages were eliminated with alkaline stabilization but were only reduced to $3.52 \log \mathrm{CFU} / \mathrm{g}$ with the dewatering method. Dewatering on drying beds produced biosolids that can be used for soil restoration. Whereas alkaline stabilization produced biosolids that can be used for agricultural purposes. Alkaline stabilization with $9 \%$ and $13 \%$ calcium oxide ostensibly reduced nitrogen and phosphorus contents in the sludge, whereas $7 \%$ calcium affected less the phosphorus concentration of the sludge. These results indicate that sludge dewatering on drying beds is an effective sludge sanitation protocol to be in implemented in small wastewater treatment plants, such that in Sotaquirá, Colombia.
\end{abstract}

Keywords: Drying beds; alkaline stabilization; wastewater sludge; biosolids; pathogens; organic carbon.

\section{Introduction}

Wastewater sludge is a by-product of wastewater treatment. Under ideal circumstances, this sludge is treated and disposed or applied on the soil for its development. Currently, the rapid and massive accumulation and inappropriately treated wastewater sludge is a matter of concern because of its negative effects on the environment and public health [1-3]. To minimize 
these negative impacts, several countries have encated policies that require stabilization and removal of sewage sludge prior to its soil application [4-6]. In this regard, Colombian regulations deem sewage sludge stabilization as a way to reduce pathogens and further classify its biosolids, based on their physicochemical and microbiological properties, into categories $\mathrm{A}$ and $\mathrm{B}$ (see Table 1 and Table 3). Wastewater sludge type A biosolids can be used for agricultural purposes without restrictions. Whereas, sewage sludge type B biosolids can only be used for soil restoration [4].

In Colombia, $97 \%$ of the sludge produced by wastewater treatment plants (WWTP) is generated in the three major urban areas, Bogotá, Cali, and Medellín [7]. The remaining $3 \%$ is produced by several small municipal plants across the country. In these municipal WWTPs knowledge about how to appropriately manage growing sewage sludge is missing. Usually, these WWTPs dispose the sludge on nearby fields or give it away to local farmers without any treatment, oblivious of the negative impact of their practices on the environment and the public health.

The wastewater treatment plant in the locality of Sotaquirá, (Department of Boyacá) Colombia, produces 109 tons of total solids per year. The sewage sludge generated by this plant is disposed on sludge drying beds for a short period of time, usually less than two months, due to its limited storage capacity. Then, it is given away to local farmers without any further treatment. This is seen as a win-win situation for the plant managers and the farmers because the plant gets rid of the by-product and the farmers use it to increase the productivity of their crops. However, they do not realize the negative health and environmental consequences that this practice may cause. This sewage sludge exceeds the pathogenic microorganism concentrations permitted for agricultural purposes or soil restoration [4]. This problem exists even though there are several stabilization techniques that have been proven to successfully reduce the pathogenic bacteria concentration to the required levels by local regulations.

Some of the stabilization techniques available include sludge anaerobic digestion [8], drying of sewage sludge on radiant floors using solar energy and biogas [9], sludge dewatering on drying beds [10-11], composting [12], and alkaline stabilization [13-16]. In this paper, we present the results of the evaluation of two of these stabilization methods on the sewage sludge generated by the WWTP of Sotaquirá: sludge dewatering on drying beds and alkaline stabilization. These methods were chosen because of their operational simplicity, low consumption of energy, and a low level of investment. In particular, we carried out physicochemical and microbiological analyses to evaluate whether or not these methods produce biosolids suitable for agricultural use or soil restoration. 
Table 1. Sewage sludge biosolids classification a ccording t o Colombian regulations, based on microbiological variables.

Variable

\begin{tabular}{lcc}
\hline Fecal coliforms $(\log \mathrm{CFU} / \mathrm{g})$ & $<3.00$ & $<6.30$ \\
\hline Somatic phages $(\log \mathrm{PFU} / \mathrm{g})$ & $<4.70$ & - \\
\hline Viable helminth eggs $(\mathrm{HH} / 4 \mathrm{~g})$ & $<1.00$ & $<10.00$ \\
\hline Salmonella $\mathrm{sp} .(\mathrm{CFU} / 25 \mathrm{~g})$ & 0 & $<1.000$ \\
\hline
\end{tabular}

\section{Materials and methods}

\section{Description of the area of study}

The wastewater treatment plant is located in Sotaquirá, in the department of Boyacá, Colombia $\left(5^{\circ} 45^{\prime} 4^{\prime \prime} \mathrm{N}, 73^{\circ} 14^{\prime} 50.9^{\prime \prime}\right.$ W) at 2860 meters above sea level. The average annual temperature of this locality is $14^{\circ} \mathrm{C}$ with an average annual relative humidity of $80 \%$, an average annual precipitation of $1260 \mathrm{~mm}$, and an average wind speed of $21 \mathrm{Km} / \mathrm{h}$. The main economic activity of this town is dairy production and all its discharges flow into the sewage system. The wastewater treatment plant treats an average flow of $1.72 \mathrm{~L} / \mathrm{s}$.

\section{Collection of samples}

The wastewater sludge accumulated in an Imhoff tank is uniformly distributed on one of the two sludge drying beds available. The sludge drying bed used in this study has an effective area of $5.5 \mathrm{~m}^{2}$. A transparent plastic sheet was used to block rainfall without blocking solar radiation. The drying process consisted of sun exposure for five months. During this period, dewatering sludge was sampled monthly from the surface of the bed. Each sample was taken by digging small holes from several points until collecting approximately $1 \mathrm{Kg}$. The monthly samples were collected and stored in a hermetic storage bag at $4{ }^{\circ} \mathrm{C}$ for $48 \mathrm{~h}$ before analysis. 


\section{Laboratory analyses}

Physicochemical and microbiological analyses were carried out on the collected samples. Prior to analysis, the samples were pulverized and sieved through a $1.18 \mathrm{~mm}$ stainless steel mesh (Endecotts, United Kingdom). As for the microbiological analysis, fecal coliforms, helminth eggs, Salmonella sp., and somatic phages were assesed. Whereas in the physicochemical analysis, heavy metals, total organic carbon (TOC), total phosphorus, organic nitrogen, $\mathrm{pH}$, humidity, conductivity, and organic matter were quantified. Heavy metal analyses were carried out only with the sample collected at the beginning of the study. Most of the other analyses were done in triplicate every month for a five-month period. The methods used for each of the analyses are listed in Table 2.

A sample of $100 \mathrm{~g}$ of WWS was collected after two months of natural dewatering in drying sludge beds. This sample was pulverized, weighed, and thouroghly mixed with reagent grade calcium oxide $(\mathrm{CaO})$ in the following three concentrations $7 \%, 9 \%$, and $13 \%$, on a dry weight basis (w/w). The three sample mixtures were analyzed at 0,12, 24, and 96 hours for total organic carbon concentration, organic matter load, total phosphorus concentration, $\mathrm{pH}$, and conductivity. Total coliforms, total helminth eggs, Salmonella sp., and somatic phages were also assesed. All data from physical-chemical variable quantifications and microbiological test results were handled and analyzed using R [17].

\section{Results and discussion}

The concentration of heavy metals in the samples of wastewater sludge from Sotaquira's WWTP are shown in Table 3. The obtained concentrations of these metals are below permited values for agricultural use without restrictions, thus this sludge can be safely assigned to category A. These results may be related to the absence of industrial and mining activity in the area of the municipality. In comparison, sludge in big cities with high industrial development presents higher values of heavy metals. For instance, readings of the WWTP of Medellin have revealed a copper in a concetration of 894.6 $\mathrm{mg} / \mathrm{Kg}$, cadmium $11.17 \mathrm{mg} / \mathrm{Kg}$, lead $94.6 \mathrm{mg} / \mathrm{Kg}$, and nickel $398.2 \mathrm{mg} / \mathrm{Kg}$ [18].

Physicochemical and microbiological features of the sludge on drying bed treatment

The sludge discharged onto the drying bed had a $\mathrm{pH}$ value of 5.5. This $\mathrm{pH}$ value could be explained by fermentation of organic matter by facultative anaerobic bacteria. After one month on the drying bed, the $\mathrm{pH}$ values increased and remained around $6.84( \pm 0.20)$ for the rest of the drying period. These results 
Table 2. Methods used for the physicochemical and microbiological analyses.

Parameters

\begin{tabular}{|c|c|}
\hline $\begin{array}{l}\text { Heavy metals (Cd, Hg, Cr, Cu, } \\
\text { Ar, Ni, Pb, Se, Zn, Mo) }\end{array}$ & $\begin{array}{l}\text { Atomic absorption } \\
\text { spectroscopy }\end{array}$ \\
\hline Total organic carbon (TOC) & Colorimetry \\
\hline Total phosphorus (P) & Colorimetry \\
\hline Organic nitrogen & Kjeldahl \\
\hline $\mathrm{pH}$ & Electrometric $2: 5$ a $25^{\circ} \mathrm{C}$ \\
\hline Humidity & Gravimetric \\
\hline Conductivity & Electrometric $1: 5\left(25^{\circ} \mathrm{C}\right)$ \\
\hline Organic matter (MO) & Calculation \\
\hline Total coliforms & $\begin{array}{l}\text { Plate-counting in Chromocult } \\
\text { agar (Merck) }\end{array}$ \\
\hline Salmonella sp. & $\begin{array}{l}\text { Salmonella in Sewage Sludge } \\
\text { (Biosolids) by Modified } \\
\text { Semisolid Rappaport-Vassiliadis } \\
\text { (MSRV) Medium. }\end{array}$ \\
\hline Total helminth eggs & Modified Bailenger method \\
\hline Somatic phages & Double-agar-layer method \\
\hline
\end{tabular}

differ from the results obtained by Cota-Espericueta and Ponce-Corral using a solar dryer [19]. They observed an initial $\mathrm{pH}$ level of 6.8. After 74 hours, the $\mathrm{pH}$ decreased to 6.07 reaching a level of 6.0 by the end of the eleven-day treatment.

The TOC in the sludge exiting the water treatment plant was $44.00 \%( \pm 0.17)$. During the five-month drying period, the content of organic carbon decreased steadily, reaching $37.3 \%( \pm 1.53)$ (Fig. 1). This decreasing trend has been observed in other studies $[11,20,21]$; however, in the present study the rate was less steep. Furthermore, the TOC levels measured during all the drying period in this study are higher than the observed in other studies $[11,20]$. 
Table 3. Heavy metals present in the sludge of Sotaquirá wastewater treatment plant in contrast to maximum permitted values for biosolid categories $\mathrm{A}$ and $\mathrm{B}$, according Colombian regulations. LQ (limit of quantification) $\mathrm{Hg}: \mathrm{mg} / \mathrm{kg}$; Mo: $\mathrm{mg} / \mathrm{kg}$.

\begin{tabular}{|c|c|c|c|}
\hline Metal & $\begin{array}{c}\text { Result } \\
\text { (mg/kg) }\end{array}$ & $\begin{array}{c}\text { Category A } \\
\text { (mg/kg) } \\
\text { threshold }\end{array}$ & $\begin{array}{c}\text { Category B } \\
\text { (mg/kg) } \\
\text { threshold }\end{array}$ \\
\hline & 1.00 & 1.00 & 1.00 \\
\hline Arsenic (As) & $<1.8$ & 20 & 40 \\
\hline Cadmium (Cd) & $<1.8$ & 8 & 40 \\
\hline Copper (Cu) & $<18$ & 1000 & 1750 \\
\hline Chromium (Cr) & $<18$ & 1000 & 1500 \\
\hline Mercury (Hg) & $<\mathrm{LQ}$ & 10 & 20 \\
\hline $\begin{array}{l}\text { Molybdenum } \\
\text { (Mo) }\end{array}$ & $<\mathrm{LQ}$ & 18 & 75 \\
\hline Nickel (Ni) & $<18$ & 80 & 420 \\
\hline Lead $(\mathrm{Pb})$ & $<18$ & 300 & 400 \\
\hline Selenium (Se) & $<1.8$ & 36 & 100 \\
\hline Zinc (Zn) & 82 & 2000 & 2800 \\
\hline
\end{tabular}

The temporal profile for total phosphorus is displayed in Fig. 2. Before the second month, total phosphorus remained around $5.21 \%( \pm 0.15)$. In the second month, the average concentration was reduced to $4.73 \%( \pm 0.05)$. From the second to the fifth months, the concentration increased steadily until reaching a concentration of $5.08 \%( \pm 0.06)$. Regarding organic nitrogen, its values fluctuated around $1.91 \%( \pm 0.32)$. The total phosphorus and organic nitrogen values measured at this plant were higher than those reported by other domestic wastewater treatment plants [11,21-23]. These high levels are attributable to the main local economic activity of the municipality, which is the production of artisanal dairy products. 


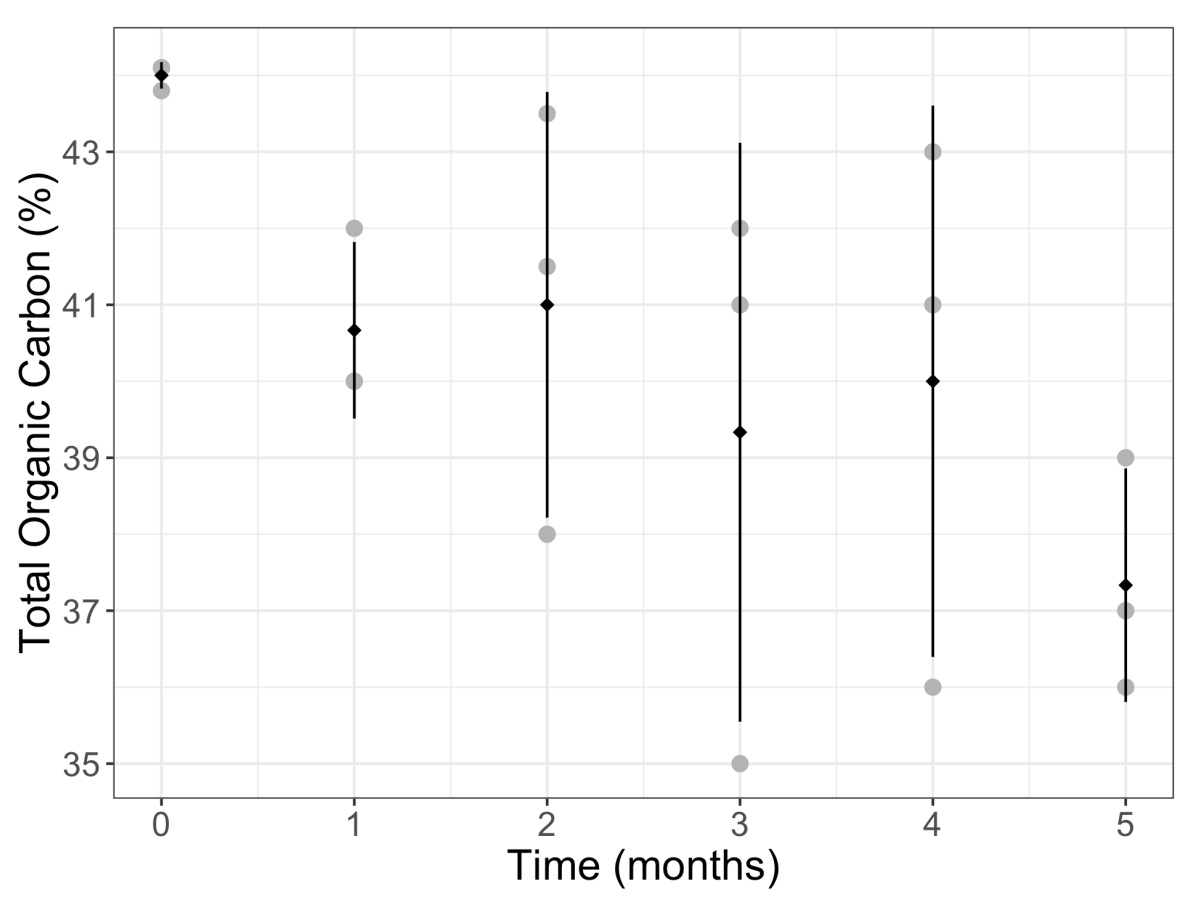

Figure 1. Temporal profile of t otal o rganic carbon $\mathrm{c}$ ontent. The g ray dots represent the observed values, the black points correspond to the average, and the vertical lines indicate the average \pm one standard deviation.

Microbiological analyses showed that the five-month sludge drying process on drying bed had a significant influence on the pathogenic microorganisms. By the fourth month of drying, Salmonella sp., was not detected. This absence could be justified by the fact that Salmonella sp. is a microorganism sensitive to desiccation and is often outcopided by other microorganisms $[24,25]$.

Fecal coliforms decreased from $10.9 \log \mathrm{CFU} / \mathrm{g}( \pm 0.07)$ to $4.11 \log \mathrm{CFU} / \mathrm{g}$ $( \pm 0.08)$ during this study. Whith the first two months, fecal coliforms decreased more rapidly than in the third to the fifth months (Fig. 3). The pattern of decrease of fecal coliforms concentrations matches that observed for humidity. Humidity was reduced by $88.9 \%$ at the end of the second month (Fig. 3); subsequently, it remained relatively constant and reached its lowest point $(<6 \%)$ by the end of the fifth month.

Fig. 4 displays the number of total helminth eggs found in the monthly samples. A high prevalence of Ascaris lumbricoides (57\%) was observed, followed by Fasciola sp., Diphyllobothrium sp., Clonorchis sp., Schistosoma spp. and Hookworm sp. The mean number of total helminth eggs and its variability decreased with time. An average of $9( \pm 7.55)$ total helminth eggs were found in the sludge sample leaving the treatment plant. After five months on the drying bed, only one egg was found on one of the three samples. 


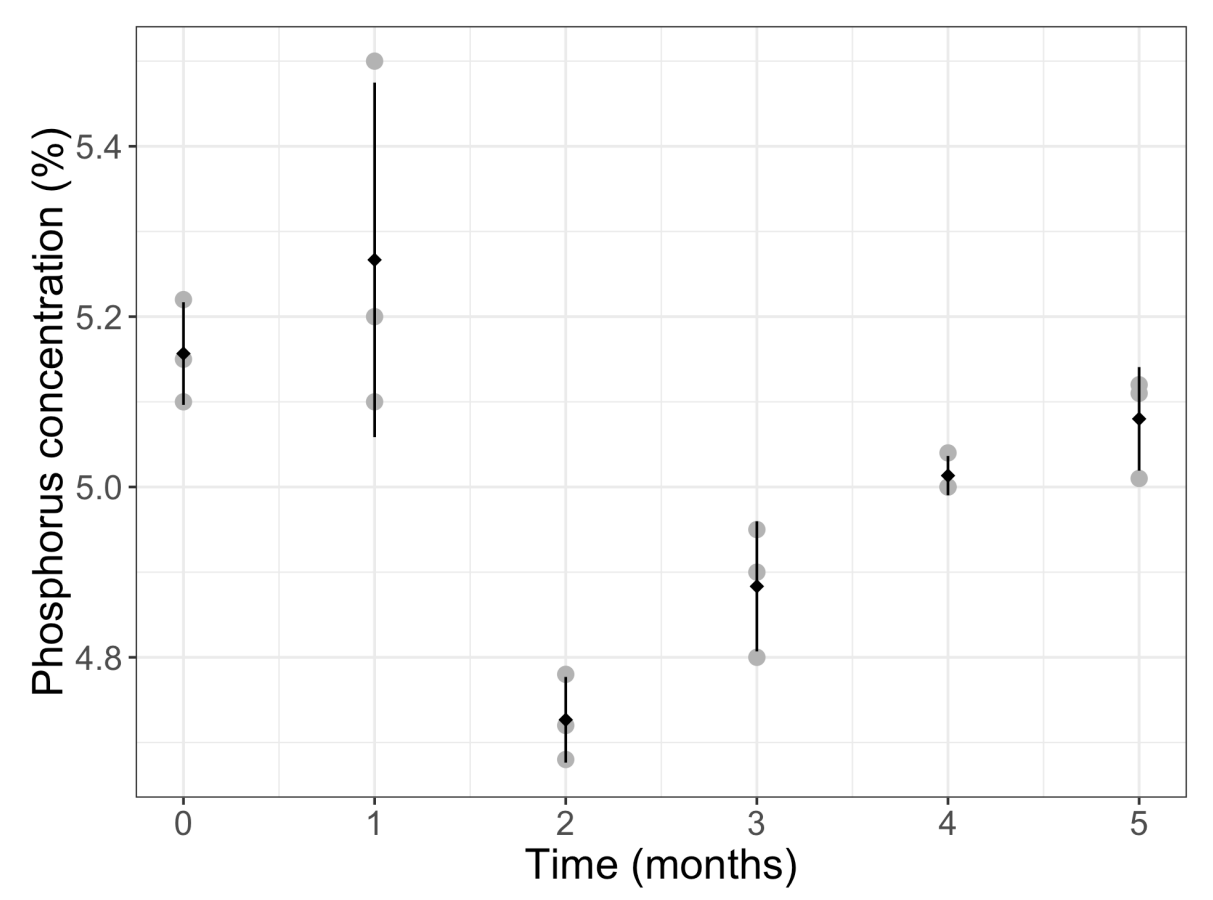

Figure 2. Temporal profile of phosphorus $\mathrm{c}$ oncentration. The black points correspond to the average for each month and the black line represents the average plus and minus the standard deviation.

An average of $4.36( \pm 0.312) \log \mathrm{CFU} / \mathrm{g}$ somatic phages were observed in the sludge exiting the treatment plant. After two months on drying beds, the log $\mathrm{CFU} / \mathrm{g}$ somatic phages decreased to 3.52 ( \pm 0.03 ). However, after this initial decrease, there was no change in the somatic phages content. These results are consistent with those reported by Shanahan and Campos [24-26].

Physicochemical and microbiological features of sludge under alkaline stabilization

The application of $\mathrm{CaO}$ at different doses $(7 \%, 9 \%$, and $13 \%)$ produced an increase in the $\mathrm{pH}$ of the sludge. The $\mathrm{pH}$ of the sludge treated with the highest concentration of $\mathrm{CaO}(13 \%)$ increased to 12 and remained at this level for more than 96 hours (Fig. 5). This treatment complies with one of the alternatives given by the Environmental Protection Agency (EPA) and Colombian regulations to obtain type A sewage sludge [4]. In contrast, the average sludge $\mathrm{pHs}$ achieved with $\mathrm{CaO}$ concentrations of $9 \%$ and $7 \%$ were 11.65 and 11.09 , respectively. 


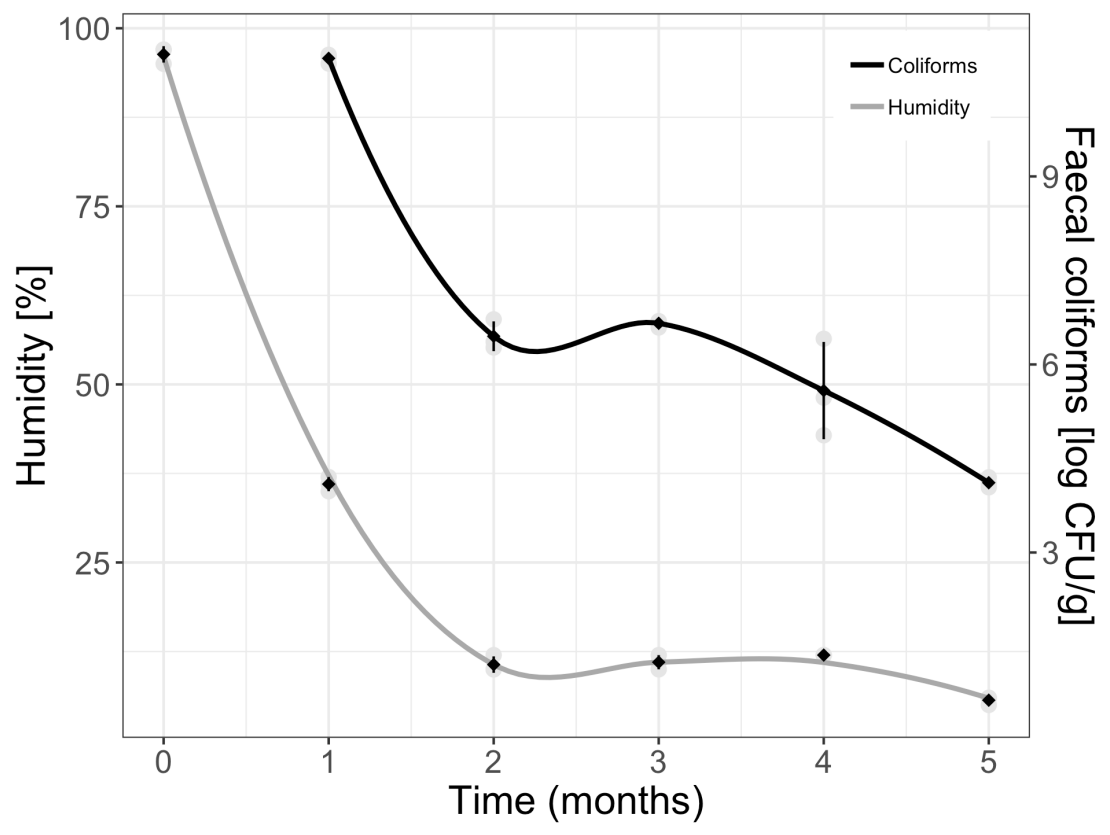

Figure 3. Temporal profile of fecal coliforms and humidity. Black points correspond to the monthly averages and black vertical lines denote the corresponding, plus and minus, standard deviations.

Alcaline treatment with $13 \% \mathrm{CaO}$ led to an immediate total reduction of fecal coliforms, Salmonella sp., and somatic phages. In the case of helminth eggs, no eggs were detected at time 0 and after 12 hours, but one helminth egg was

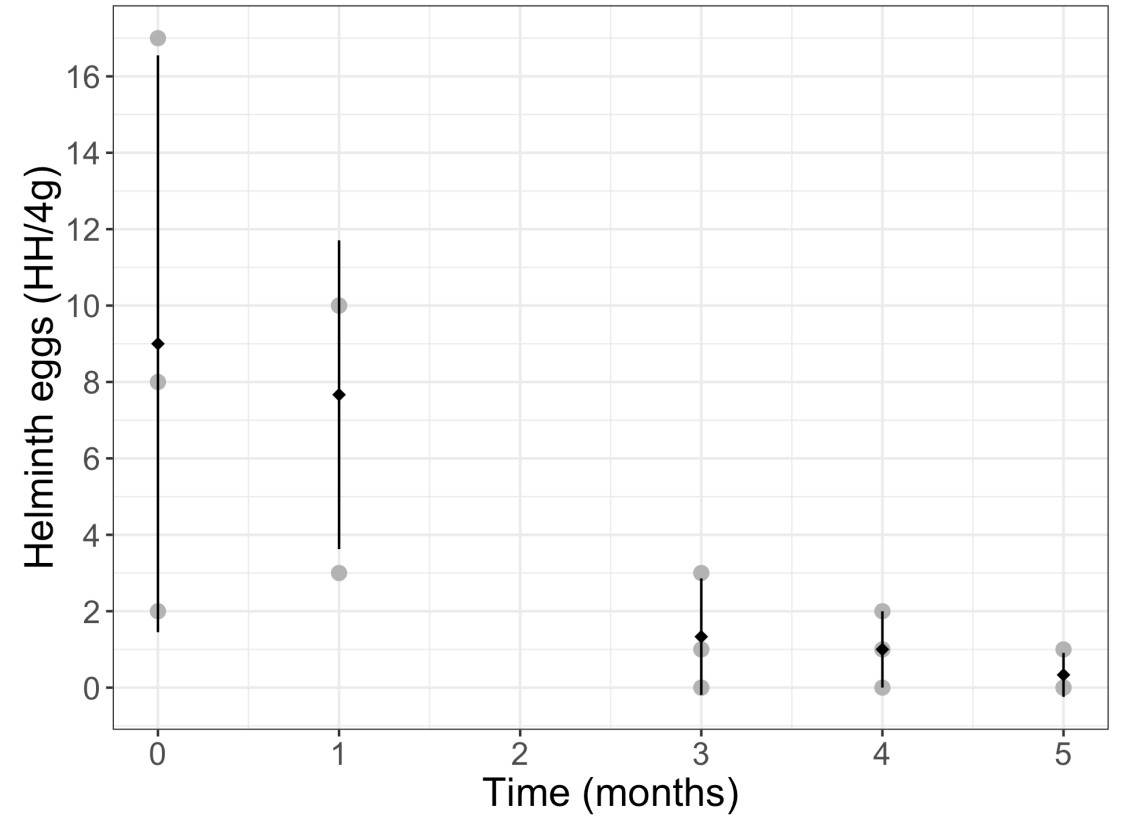

Figure 4.Temporal profile of helminth eggs. Black points correspond to monthly averages and black line denote the corresponging plus and minus standard deviations. 


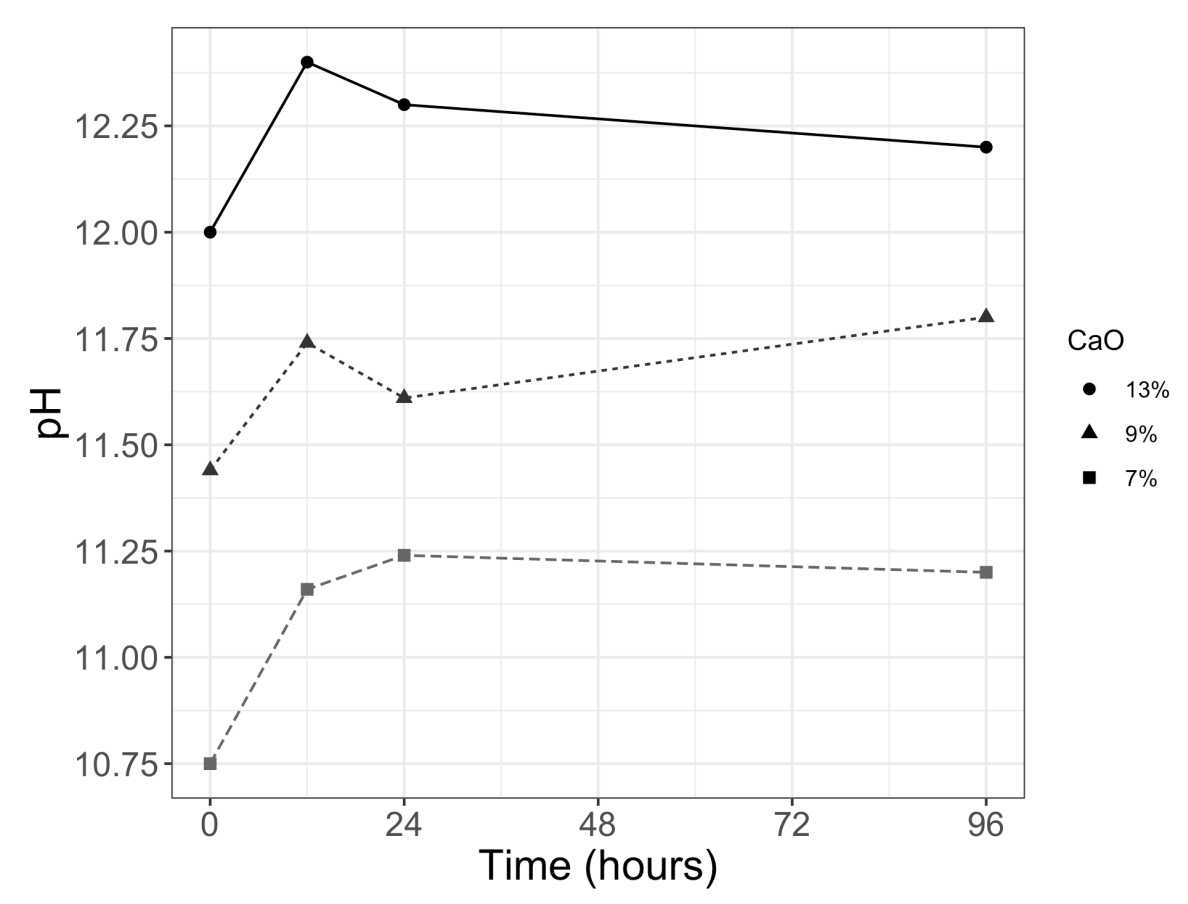

Figure 5. Effect of $\mathrm{CaO}$ concentration on sludge $\mathrm{pH}$ for 96 hours.

detected in one of the three samples 24 hours after treatment. No helminth eggs were detected 96 hours after treatment. Alcaline treatment with $\mathrm{CaO}$ at concentrations of $9 \%$ and $7 \%$ eliminated the fecal contamination indicators after 24 hours and 4 days of exposure, respectively. This elimination is due to the increase in temperature and $\mathrm{pH}$ for two or more hours with release of gases and hindering of pathogen reproduction [27]. Both of these concentrations also eliminated Salmonella sp., right after application. Helminth eggs were also eliminated with these two $\mathrm{CaO}$ concentrations. The application of $9 \%$ $\mathrm{CaO}$ resulted in the elimination of all helminth eggs after 12 hours, whereas $7 \% \mathrm{CaO}$ elimanted all eggs at 24 hours. Somatic phages were eliminated after 12 hours with both concentrations.

Sludge treatment with $13 \% \mathrm{CaO}$ led to results similar to those obtained by Torres et al [28] with $15 \% \mathrm{CaO}$, observed helminth egg and fecal coliforms elimination at time zero. These authors also used $8 \% \mathrm{CaO}$ and found that helminth eggs were also eliminated at time zero, whereas fecal coliforms were eliminated by the sixth day after application. Silva-Leal et al obtained comparable results for helminth eggs with $\mathrm{CaO}$ at concentrations of $8 \%, 8.5 \%$, $9.0 \%, 9.5 \%$, and $10 \%$ [29]. Furthermore, contrary to the results reported by Torres et al [28] and the present study, Silva-Leal and collegaues did not detect coliforms at the time of $\mathrm{CaO}$ application, regarless of its concentration. 
Another difference to the present study is that they reached a $\mathrm{pH}$ of 12 with all tested $\mathrm{CaO}$ concentrations for more than 72 hours as required by EPA.

The treatment with $7 \% \mathrm{CaO}$ resulted in sludge phosphorus concentrations of $4.6 \%$ and $4.3 \%$ at the time of application and at $24 \mathrm{~h}$ after application, respectively. These concentrations are slightly lower than the ones obtained without alkaline stabilization. On the other hand, in the mixtures treated with $9 \%$ and $13 \% \mathrm{CaO}$ phospohorus concentrations at $24 \mathrm{~h}$ after application were of $1.0 \%$ and $0.5 \%$, respectively. The concentrations of organic nitrogen in the sludge mixtures treated with $13 \%, 9 \%$, and $7 \% \mathrm{CaO}$ were $1.2 \%, 0.9 \%$, and $1.1 \%$, respectively. These values are all lower than the obtained without alkaline stabilization.

Based on the physicochemical analysis and microbiological assessment results, we were able to ascertain that sludge dewatering on drying beds is an effective treatment to reduce fecal pollution indicators without altering the sludge's physicochemical properties of agricultural importance. In this study, the biosolid obtained using drying beds was of category B according to Colombian regulations, failing to meet criteria to be considered as a category $\mathrm{A}$ biosolid because of reported fecal coliform concentrarions. Given that sludge dewatering on drying beds is a process where sunlight and wind stabilize the sludge, it is regarded as a low-cost process with operational simplicity and limited energy consumption. Thus, it is a viable alternative to treat the sludge produced by small WWTPs. However, it requires space and infrastructure that several small plants may not have. On the other hand, alkaline stabilization requires less time and less space; however, the treatment of all the sludge produced will require large quantities of $\mathrm{CaO}$. Therefore, it is desirable to use the minimal concentration of $\mathrm{CaO}$ that can reduce fecal pollution indicators. For the small WWTP under study, alkaline stabilization with $7 \% \mathrm{CaO}$ can yield A category biosolids.

\section{Conclusions}

The physicochemical characterization carried out on the sludge generated in the Sotaquirá WWTP suggests that this sludge has potential agricultural use due to its high content of total organic matter, organic elemnts (carbon, phosphorus, and nitrogen), and low levels of heavy metals. The two stabilization treatments used allowed to establish a viable alternative in the sanitization of sludge for agricultural applications with some restrictions. In the case of dewatering using drying beds, a category B biosolid was obtained after five months of treatment without affecting the physicochemical characteristics of the sludge. In contrast, alkaline stabilization with $\mathrm{CaO}$ concentrations of $7 \%, 9 \%$, and $13 \%$ reduced sludge pathogen loads, successfully yielding biosolids of the A category. Notably, the two low concentrations of $\mathrm{CaO}$ did not reach $\mathrm{pH}$ levels of 12 units as recommended 
by EPA. The time required to achieve a category A biosolid increased when the concentration of $\mathrm{CaO}$ was lower. Nonethless, it is recommended to use $7 \% \mathrm{CaO}$ because at this concentration the physicochemical characteristics of the sludge remained unaffected.

Although category A biosolids can be achieved with alkaline stabilization, small WWTPs in Colombia are usually unaware of the potential agricultural use of these biosolids and are not willing to invest in this alternative. Dewatering on drying beds could be the most accessible sludge treatment type for small WWTPs. However, a longer drying time should be considered to reduce the load of pathogenic microorganisms yielding a biosolid suitable for agricultural use.

\section{Acknowledgments}

The authors thank Dra. Claudia Campos Pinilla for the phage and strain of E. coli for the determination of somatic phages. This work was supported financially by the University of Boyacá, Tunja, Colombia.

\section{Conflict of interest}

The authors have no conflicts of interest to declare.

\section{References}

[1] Clarke R, Peyton D, Healy MG, Fenton O, Cummins E. A quantitative microbial risk assessment model for total coliforms and E. coli in surface runoff following application of biosolids to grassland. Environmental Pollution, 224: 739$750,2017$.

doi: 10.1016/j.envpol.2016.12.025

[2] Semblante GU, Hai FI, Huang X, Ball AS, Price WE, Nghiem L.D. Trace organic contaminants in biosolids: Impact of conventional wastewater and sludge processing technologies and emerging alternatives. Journal of Hazardous Materials, 300: 1-17, 2015.

doi: 10.1016/j.jhazmat.2015.06.037

[3] Anjum M, Al-Makishaha NH, Barakat MA. Wastewater sludge stabilization using pre-treatment methods, Process Safety and Environmental Protection, 102:615-632, 2016.

doi: 10.1016/j.psep.2016.05.022 
[4] Colombia (2014) Ministerio de Vivienda, Ciudad y Territorio. Decreto 1287 del 10 de julio de 2014. Criterios para el uso de biosólidos generados en plantas de tratamiento de aguas residuales municipales.

Retrieved from:

http:/ / www.minvivienda.gov.co/Decretos $\% 20$

Vivienda/1287\%20-\%202014.pdf

[5] Bittencourt S, Serrat BM, Aisse MM, Gomes D. Sewage sludge usage in agriculture: A case study of its destination in the Curitiba metropolitan region, Paraná, Brazil. Water, Air, and Soil Pollution, 225: 2014.

doi: $10.1007 /$ s11270-014-2074-y

[6] Mattsson A, Finnson A, I'Ons D. Heavy metal content of Swedish municipal wastewater sludge - status and goals. Water Science \& Technology, 76(3-4):869-876, 2017.

doi: $10.2166 /$ wst.2017.277

[7] Superintendencia de Servicios Públicos Domiciliarios. Estudio Sectorial de los servicios Públicos domiciliarios de Acueducto y Alcantarillado - 2016.

Retrieved from:

https://www.superservicios.gov.co/sites/default/archivos/ SSPD \%20Publicaciones/Publicaciones/2018/Oct/estudio_ sectorial-compilado-26-12-2017-vbibiana.pdf.

[8] Pilli S, Yan S, Tyagi, RD, Surampall, RY. Overview of fenton pre-treatment of sludge aiming to enhance anaerobic digestion, Reviews in Environmental Science and Biotechnology, 14: 453-472, 2015.

doi: 10.1007/s11157-015-9368-4

[9] Gontijo JC, Wagner LG, Souza ME de, Possetti GRC. Sanitation and drying of sewage sludge on radiant floors using solar energy and biogas: comparison between different thicknesses of deposited mass. Brazilian Archives of Biology and Technology, 61: 2018.

doi: 10.1590/1678-4324-smart-2018000037

[10] Pompeo RP, Andreoli CV, De Castro EA, Aisse MM. Influence of long-term storage operating conditions on the reduction of viable ascaris eggs in sewage sludge for agricultural reuse. Water, Air, and Soil Pollution, 227:144, 2016.

doi: $10.1007 /$ s11270-016-2816-0 
[11] Santos DS, Teshima E, Furiam DSM, Araújo RA, Rodrigues da Silva, CM. Effect of bed drying on the physicochemical and microbiological characteristics of sludge from upflow anaerobic blanket reactor used in sewage treatment. Engenharia Sanitária e Ambiental, 22(1): 341-349, 2017.

doi: 10.1590/S1413-41522016100531

[12] Awasthi MK, Wang Q, Chen H, Awasthi SK, Wang M, Ren $\mathrm{X}$, Zhao J, Zhang Z. Beneficial effect of mixture of additives amendment on enzymatic activities, organic matter degradation and humification during biosolids co-composting, Bioresource Technology, 247: 138-146, 2018.

doi: 10.1016/j.biortech.2017.09.061

[13] Lopes BC, Machado EC, Rodrigues HF, Leal CD, de Araújo JC, de Matos AT. Effect of alkaline treatment on pathogens, bacterial community and antibiotic resistance genes in different sewage sludges for potential agriculture use. Environmental Technology, 0: 1-10, 2018.

doi: $10.1080 / 09593330.2018 .1505960$

[14] Romero-Flores A, McConnell LL, Hapeman CJ, Ramirez M, Torrents A. Evaluation of an electronic nose for odorant and process monitoring of alkaline-stabilized biosolids production. Chemosphere, 186: 151-159, 2017.

doi: 10.1016/j.chemosphere.2017.07.135

[15] Bittencourt S, Aisse MM, Serrat, BM. Agronomic and inorganic parameters of sewage sludge sanitized by alkaline stabilization: A case study of the state of Paraná, Brazil. Scientia Agraria, 17(2): 1-13, 2016.

Retrieved from:

http://www.redalyc.org/articulo.oa?id=99549536001

[16] Zhen G, Lu X, Kato H, Zhao Y, Li YY. Overview of pretreatment strategies for enhancing sewage sludge disintegration and subsequent anaerobic digestion: Current advances, full-scale application and future perspectives. Renewable and Sustainable Energy Reviews, 69: 559-577, 2017.

doi: 10.1016/j.rser.2016.11.187 
[17] R Core Team R: A language and environment for statistical computing. R Foundation for Statistical Computing, Vienna, Austria, 2018.

Retrieved from:

https://www.R-project.org

[18] Bedoya-Urrego K, Acevedo-Ruíz J, Peláez-Jaramillo C, AgudeloLópez S. The characterization of biosolids produced by the San Fernando wastewater treatment plant in Itagui, Antioquia, Colombia. Revista de Salud Pública, 15(5):778-790, 2013.

Retrieved from:

http: / / www.scielo.org.co/scielo.php? script=sci_ arttext\&pid $=$ S0124-00642013000500013

[19] Cota-Espericueta A, Ponce-Corral C. Elimination of pathogenic bacteria in residual sludge during solar drying. Revista Internacional de Contaminación Ambiental, 24 (4): 161-170, 2008.

Retrieved from:

http://www.redalyc.org/pdf/370/37011665002.pdf

[20] Correia, JE. Caracterização físico-química e microbiológica do lodo gerado na estação de tratamento de esgoto contorno. Feira de Santana, BA. Revista eletrônica de gestão e tecnologia ambiental, 2: 2, 2014. doi: $10.17565 /$ gesta.v2i2.12789

[21] Goberna M, Simón P, Hernández MT, García, C. Prokaryotic communities and potential pathogens in sewage sludge: Response to wastewaster origin, loading rate and treatment technology. Science of the Total Environment, 615: 360-368, 2018.

doi: 10.1016/j.scitotenv.2017.09.240

[22] Belloulid MO, Hamdi H, Mandi L, Ouazzani N. Solar drying of wastewater sludge: a case study in Marrakesh, Morocco. Environmental Technology, 1-7, 2018.

doi: $10.1080 / 09593330.2017 .1421713$

[23] Torres L P, Madera PCA, Silva J. Eliminating pathogens in biosolids by alkaline stabilization. Acta Agronomica, 58(3):197-205, 2009.

Retrieved from:

http://www.scielo.org.co/pdf/acag/v58n3/v58n3a12.pdf 
[24] Shanahan E, Roiko A, Tindale N, Thomas M, Walpole R, Kurtböke I. Evaluation of pathogen removal in a solar sludge drying facility using microbial indicators. International Journal of Environmental Research and Public Health, 7: 565-582, 2010.

doi: 10.3390/ijerph7020565

[25] Ellis S, Tyrrel S, O’Leary E, Richards K, Griffiths B, Ritz, K. Proportion of sewage sludge to soil influences the survival of Salmonella Dublin and Escherichia coli. Clean - Soil, Air, Water, 46(4): 2018.

doi: $10.1002 /$ clen.201800042

[26] Campos MC, Medina LK, Fuentes NP, García GI. Assessment of indicators of fecal contamination in soils treated with biosolids for growing grasses. Universitas Scientiarum, 20 (2): 217-227, 2015. doi: 10.11144/Javeriana.SC20-2.aifc

[27] Al-Gheethi AA, Efaq AN, Bala JD, Norli I, Abdel-Monem MO, Kadir MO Ab. Removal of pathogenic bacteria from sewagetreated effluent and biosolids for agricultural purposes. Applied Water Science, 8: 74, 2018.

doi: 10.1007/s13201-018-0698-6

[28] Torres LP, Madera CA, Silva J. Microbiological quality improvement of biosolids from domestic wastewater treatment plants. Escuela de Ingenieria de Antioquia EIA, 11: 21-37, 2009.

Retrieved from:

http://www.scielo.org.co/pdf/eia/n11/n11a03.pdf

[29] Silva-Leal J, Bedoya-Ríos D, Torres-Lozada P. Effect of thermal drying and alkaline treatment on the microbiological and chemical characteristics of biosolids from domestic wastewater treatment plants. Quimica Nova, 36(2):207-214, 2013.

Retrieved from:

http://www.scielo.br/pdf/qn/v36n2/v36n2a02.pdf 


\section{Evaluación de dos métodos de estabilización de lodos en una planta de tratamiento de aguas residuales en Sotaquirá, Colombia}

Resumen: El lodo es un subproducto del tratamiento de aguas residuales y es frecuentemente empleado en procesos agrícolas después de una adecuada estabilización microbiológica. En este estudio se evaluaron dos métodos de estabilización de lodos en la planta de tratamiento de aguas residuales de Sotaquirá, Colombia. Los dos métodos evaluados fueron: deshidratación en lechos de secado y estabilización alcalina. La estabilización a través de deshidratación en lechos de secado se llevó a cabo por cinco meses; la estabilización alcalina se evaluó bajo tres concentraciones de óxido de calcio: $7 \%$, $9 \%$ y $13 \%$ p/p. Los parámetros de humedad, $\mathrm{pH}$, carbono orgánico, fósforo, nitrógeno orgánico, coliformes fecales, fagos somáticos, huevos de helminto totales y Salmonella sp. se monitorearon mensualmente en el lodo en deshidratación, y a las 0,12, 24 y 96 horas en el lodo bajo estabilización alcalina. Ambos tratamientos eliminaron Salmonella sp. del lodo. Los huevos de helminto se eliminaron con estabilización alcalina, y con el tratamiento de deshidratación se redujeron a uno o cero. Los fagos somáticos se eliminaron con estabilización alcalina, pero se redujeron solamente a $3.52 \mathrm{log} \mathrm{UFC} / \mathrm{g}$ con el método de deshidratación. La deshidratación en lechos de secado produjo biosólidos que pueden utilizarse en restauración de suelos, mientras la estabilización alcalina produjo biosólidos que se pueden usar con propósitos agrícolas. La estabilización alcalina con $9 \%$ y $13 \%$ de óxido de calcio redujo ostensiblemente los contenidos de nitrógeno y fósforo del lodo, mientras que el calcio al $7 \%$ afectó menos la concentración de fósforo. Estos resultados indican que la deshidratación en lechos de secado es un protocolo efectivo de estabilización de lodos, que puede ser implementado en plantas pequeñas de tratamiento de aguas residuales, como la de Sotaquirá, Colombia.

Palabras clave: Lechos de secado, estabilización alcalina; lodo de aguas residuales; biosólidos; patógenos; carbono orgánico. 


\section{Avaliação de dois métodos de estabilização de lodos em uma planta de tratamento de águas residuais em Sotaquirá, Colômbia}

Resumo: O lodo é um subproduto do tratamento de águas residuais e é frequentemente empregado em processos agrícolas depois de uma adequada estabilização microbiológica. Neste estudo avaliaram-se dois métodos de estabilização de lodos em uma planta de tratamento de águas residuais em Sotaquirá, Colômbia. Os dois métodos avaliados foram: desidratação em leitos de secagem e estabilização alcalina. A estabilização através de desidratação em leitos de secagem foi realizada durante 5 meses; a estabilização alcalina se avaliou em três concentrações de óxido de cálcio: $7 \%$, $9 \%$, e $13 \%$ p/p. Os parâmetros de humidade, $\mathrm{pH}$, carbono orgânico, fósforo, nitrogênio orgânico, coliformes fecais, fados somáticos, ovos de helmintos totais e Salmonella sp. Foram monitorados mensalmente no lodo em desidratação, e as 0,12, 24 y 96 horas nos lodos em estabilização alcalina. Ambos tratamentos eliminaram Samonella sp do lodo. Os ovos de helmintos se eliminaram com estabilização alcalina, e com o tratamento de desidratação se reduziram a um ou zero. Os fagos somáticos se eliminaram com estabilização alcalina, mas com o método por desidratação unicamente se reduziram a $3.52 \log \mathrm{UFC} / \mathrm{g}$. A desidratação em leitos de secagem produziu biosólidos que podem ser utilizados em restauração de solos, enquanto a estabilização alcalina produziu biosólidos que podem ser usados com propósitos agrícolas. A estabilização alcalina com $9 \%$ y $13 \%$ de óxido de cálcio reduziu ostensivamente os níveis de nitrogênio e fósforo do lodo, enquanto o cálcio a $7 \%$ afetou menos a concentração de fósforo. Estes resultados indicam que a desidratação em leito de secagem é um protocolo efetivo de estabilização de lodos, que pode ser implementado em plantas pequenas de tratamento de águas residuais, como a de Sotaquirá, Colômbia.

Palavras-chave: Leitos de secado; estabilização alcalina; lodo de águas residuais; biosólidos; patógenos; carbono orgânico. 


\section{José Castellanos Rozo}

Associate Professor in the Department of Biology and Microbiology at the Universidad de Boyacá. Ph.D. (c) in Food safety from the University of Jaén, Master's degree in Sciences Microbiology from the Universidad Nacional de Colombia, Professional in Microbiology from the Universidad de Pamplona. Research experience as a principal researcher and co-researcher in the area of Microbiology and molecular Biology.

ORCID: 0000-0001-7497-5917

\section{Jaqueline Arleth Galvis López}

Professional in food chemistry with a master's degree in biological sciences from the pedagogical and technological university of Colombia. Associate professor at the University of Boyacá, experience in research in the areas of physicochemical and environmental analysis.

ORCID: 0000-0003-4318-3188

\section{Nuri Andrea Merchán Castellanos}

Professional in Biological Sciences with PhD in Biotechnology from the University of Sao Paulo and undergraduate in Industrial Microbiology from the Universidad Javeriana. Research experience as a principal researcher and co-researcher in the areas of environmental and food microbiology, biotechnology and bioprospecting, applying tools of molecular biology, bioinformatics and bioprocesses.

ORCID: 0000-0001-5885-850X

\section{Elsa Helena Manjarres Hernández}

Biologist with a Master's Degree in Biological Sciences, Ph.D. student in Biological and Environmental Sciences of the Pedagogical and Technological University of Colombia. Experience in research in molecular biology and plant genetics.

ORCID: 0000-0001-6221-8636 


\section{Alex L Rojas}

Associate professor of statistics at the Universidad Pedagógica y Tecnológica de Colombia. His main area of interest is the application of statistics to solve problems in his local community.

ORCID: 0000-0002-9460-8695 